\title{
Development of Human Potential in the Innovation Economy of Kazakhstan
}

\author{
Bauyrzhan S. Yessengeldin, Diana A. Sitenko \\ Y.A. Buketov Karaganda State University \\ University str. 28, 100028 Karaganda, Kazakhstan
}

\author{
Aissulu N. Ramashova \\ L.N. Gumilyev Eurasian National University \\ Mirzoyana str. 2, 010008 Astana, Kazakhstan \\ DOI:10.13165/VPA-15-14-2-04
}

\begin{abstract}
The article analyzes the current state of the labor market in the Republic of Kazakhstan and provides the dynamics of the economically active population of the country. The paper identifies positive and negative factors affecting the human potential of economic sectors of Kazakhstan. The authors disclosed structural elements of human potential: basic capacity and technological potential. The paper defines a set of target indicators influencing the formation of elements of human resources in the country. The recommendations for the involvement and training of qualified personnel for the innovation economy, taking into account various factors, are proposed.
\end{abstract}

Keywords: innovation, innovative development, labor market, human potential, the Republic of Kazakhstan.

JEL classification: H70, J01, J24

Raktažodžiai: inovacija, inovatyvi raida, darbo rinka, žmogiškieji ištekliai, Kazachstano Respublika. 


\section{Introduction}

Economic development in the modern world is characterized by the defining role of technological progress. Innovative activity at the present stage of development becomes one of the most important system factors of economic growth, an increase of competitiveness of a domestic production, providing economic security of the country.

Now, the solution of the problem of achievement of economic growth in Kazakhstan is closely connected with the accelerated development of the innovative sphere. Therefore, more often the state strategic documents set the task of the transition of the economy from export and raw type to the innovative one.

So, the main long-term reference point of development of an innovative economy of Kazakhstan is the State program of industrial and innovative development of the Republic of Kazakhstan for 2015-2019 [19]. The main directions of implementation of that program as well as the Strategy "Kazakhstan-2050" [1] are connected with the creation of the competitive human capital. Of course, the human factor is decisive in the realization of state programs. Without well-educated personnel, it is too difficult to assimilate foreign technologies which are acceptable in the world markets. The high importance of education and science should be noted in formation and development of the human capital of the Republic of Kazakhstan, where the gained knowledge becomes the key factor of innovative development of the country.

According to the State program of education development of the Republic of Kazakhstan for 2011-2020 [18], the sphere of education, firstly fundamental, should be become the main direction of the state support of the innovative economy. That is why education as a technology of generation and knowledge acquisition as well as problems of development of personnel potential gain the increasing relevance.

The issues of human resource management and human capital are considered in the works by Schultz (1961), Becker (1967), Mescon et al. (1994), Dyatlov (1996) $[4,7,11,16]$. Modern aspects of human resources in the context of human development are set out in the works of Kazakh economists Muhamedzhanova (2001), Maydyrova (2004), Meldahanova (2011), Zakirova (2012) [9, 10, 13, 22].

The orientation of companies on innovation required the development of such area as human resources of an innovative enterprise. Among the researchers who contributed in that area are primarily foreign scientists, including Vesnin (1998), Armstrong (2004), Kibanov (2002), Tripon and Blaga (2011) and others [3, 8, 20, 21]. All the authors drew attention to the link between the development of personnel potential and the overall capacity of the company, considering the structure of innovative human resources. The relationship between strategic human resource practices and innovation performance at the country level are revealed in the works by Dakhli and De Clercq (2004), Chen et al. (2009) [5, 6]. 
At the same time, the changing socio-economic conditions, as well as the experience gained in the course of work, made it necessary to highlight the role of human resources in conditions of innovation economy of the Republic of Kazakhstan.

\section{Materials and methods}

The research methodology is based on the dialectical and system analysis, which is based on theoretical (analysis, synthesis) approaches.

The article is based on data of the Agency on Statistics of the Republic of Kazakhstan, the legislative and regulatory framework for education and innovation development, program documents of the Government of the Republic of Kazakhstan.

\section{Issues of human involvement in different sectors of the economy of Kazakhstan}

The study of an innovative economy is impossible without considering the labor market.

The subject of the relations in the labor market is a certain person, who disposes his own labor, finds for it application in different spheres of the market economy and develops according to his own interests.

Assessment of the situation in the labor market of Kazakhstan assumes carrying out the analysis of its structure. In modern conditions, the infrastructure of the market has to include not only processes of purchase and sale of work, the formation of employment of the population, but also a measure of social protection of the economically active population. The reasons of it are concealed, first of all, in the existence of certain contradictions between the person and economy and their decision in the conditions of an innovative economy.

Table 1. Structure of the economically active population of Kazakhstan

\begin{tabular}{|l|c|c|c|c|}
\hline \multirow{2}{*}{ Indicators } & \multirow{2}{*}{$\begin{array}{c}\text { Economically } \\
\text { active } \\
\text { population, } \\
\text { thousandpeople }\end{array}$} & $\begin{array}{c}|c| \\
\text { employed } \\
\text { population }\end{array}$ & $\begin{array}{c}\text { Including } \\
\text { unemployed } \\
\text { population }\end{array}$ & $\begin{array}{c}\text { The } \\
\text { unemployment } \\
\text { rate, \% }\end{array}$ \\
\hline Year 2009 & 8457,9 & 7903,4 & 554,5 & 6,6 \\
\hline Year 2010 & 8610,7 & 8114,2 & 496,5 & 5,8 \\
\hline Year 2011 & 8774,6 & 8301,6 & 473,0 & 5,4 \\
\hline Year 2012 & 8981,9 & 8507,1 & 474,8 & 5,3 \\
\hline Year 2013 & 9041,3 & 8570,6 & 470,7 & 5,2 \\
\hline
\end{tabular}

Source: compiled by the authors based on data from the Agency on Statistics of the Republic of Kazakhstan [2] 
Table 1 shows that in 2013 the number of economically active population of the Republic of Kazakhstan reached 9 million people, which is 59,4 thousand people $(0,7 \%)$ more than in 2012 . The level of economic activity was $71,7 \%$. At branches of the state economy in 2013, 8,6 million people were occupied. Compared with the previous year, the increase in the number was 63,5 thousand people $(0,7 \%)$.

The number of the unemployed population in 2013 was 470,7 thousand people. The unemployment rate was $5,2 \%$.

The indicator of the unemployed population will not decrease sharply for some reasons:

- The relevance of professions and labor market are changing their structure. Many specialties are losing their relevance, and in market system the process of retraining of experts happens non-systematized and during a long period of time;

- The education system is torn off from production and business in general, it complicates and raises an information gap where there is no feedback. In this connection, initially training of specialists is carried out at a low level that, in turn, lowers competitiveness of domestic labor resources;

- Globalization assumes open borders for an entrance on the market for both the international corporations and foreign labor.

On the one hand, market relations have their own laws defining the demand for human resources which are contrary to the social policy of the states. On the other hand, the state, as the subject of the market relations, can conduct the policy of employment which is not contradicting with market relations. It is obvious from the data of the employed population of the Republic of Kazakhstan by economic sector (Table 2).

Table 2. The employed population by economic sector thousand people

\begin{tabular}{|l|c|c|c|c|c|}
\hline \multicolumn{1}{|c|}{ Indicators } & Year 2009 & Year 2010 & Year 2011 & Year 2012 & Year 2013 \\
\hline The agricultural sector & 2293,3 & 2294,9 & 2196,1 & 2172,7 & 2073,6 \\
\hline Industry and Construction & 1473,1 & 1518,6 & 1574,3 & 1648,9 & 1699,1 \\
\hline Services & 4137,0 & 4300,6 & 4531,3 & 4685,5 & 4798,0 \\
\hline Total employed population & 7903,4 & 8114,2 & 8301,6 & 8507,1 & 8570,6 \\
\hline
\end{tabular}

Source: compiled by the authors based on data from the Statistics Agency of the Republic of Kazakhstan [2]

In the structure of the employed population, more than a half of the population of the Republic of Kazakhstan works in the services sector. Lack of flexible, effective social and economic policy of the state in branches of economy deforms its development, increasing a gap between the agrarian sector and the industry.

The number of the employed in the industries and constructions since 2009 (1473,1 thousand people) grew by $15,3 \%$ and in 2013 exceeded 1,6 million people 
(1699,1 thousand people). Within the Map of industrialization of the Republic of Kazakhstan in the period of 2010-2013, more than 67 thousand workplaces were created; however, these workplaces were not completely filled by the unemployed.

The main problems of non-providing workplaces with human resources are:

1) low qualification of personnel with technical and engineering skills and specialties on the basis of technical and professional education;

2) lack of knowledge of progressive advanced technologies;

3) deficiency of scientific personnel on technical, engineering specialties and innovative management;

4) insufficient harmonization of professional standards with educational standards.

To solve this problem, Kazakhstan is taking steps to attract foreign labor. The main goal in attracting foreign labor force is the implementation of innovative and technologically complex types of work, the implementation of which is difficult because there are no experts in this profession or qualifications at the local labor market. However, in order to protect the domestic labor market, the Government of the Republic of Kazakhstan annually establishes a quota on attracting foreign experts to the republic. The size of the quota depends on the number of economically active population of the republic [17].

\section{Table 3. The quota for attracting foreign experts in Kazakhstan}

\begin{tabular}{|l|c|c|c|c|c|}
\hline \multicolumn{1}{|c|}{ Indicators } & Year 2009 & Year 2010 & Year 2011 & Year 2012 & Year 2013 \\
\hline The size of the quota, \% & 0.75 & 0.75 & 0.85 & 1.0 & 1.2 \\
\hline Establishing quota, persons & 63434 & 64580 & 74584 & 89819 & 108496 \\
\hline $\begin{array}{l}\text { Visiting specialists in real } \\
\text { life, persons }\end{array}$ & 30988 & 29178 & 28753 & 23214 & 25491 \\
\hline
\end{tabular}

Source: compiled by the authors on the basis of statistical data of the Ministry of Health and Social Development of the Republic of Kazakhstan [14]

Table 3 shows that, in spite of the increase in quotas (from 63,434 people in 2009 to 108,496 persons in 2013), in recent years in the Republic of Kazakhstan there has been a tendency of reducing the amount of attracted foreign labor. In 2013, only 25,491 foreign experts worked at enterprises in Kazakhstan.

According to the social protection and migration Committee's data [12], the main countries of migrant workers continue to be the following countries: China -5659 people ( $23.6 \%$ of the total number of foreign workers), Turkey $-4,405$ people (18.4\%), India - 1815 people (7.5\%), the Republic of Serbia - 1500 people $(6.2 \%)$. More than $80 \%$ of the total number of foreign workers are involved in the construction industry and mining.

The complexity of the current legal framework and the duration of the permit procedure for attracting foreign labor lead to the fact that the quota allocated is 
not fully used. Bypassing the current legislation evolves illegal labor activities of migrants. The main problems of not mastering allocated quota on attracting foreign experts on sectors of the economy may be caused by:

1) weak interregional mobility of labor;

2) difficult procedure of receiving foreigners' working visas and the work permit in Kazakhstan.

In addition to quotas, another mechanism for limiting and regulating the composition of the foreign workforce are requirements for local content in employment. An employer who hires foreign specialists has to ensure the following requirements for local content:

- The number of citizens of the Republic of Kazakhstan should be at least $70 \%$ of the payroll number of employees related to the first and second categories (management team);

- The number of citizens of the Republic of Kazakhstan should be at least $90 \%$ of the payroll number of employees belonging to the third and fourth categories (professionals, skilled workers) [15].

Meanwhile, labor market should be considered not only as the employment regulation mechanism today, but also as the major prerequisite and a component of process of formation of the human capital of the nation through educational process in the conditions of innovative economy.

\section{Features of formation of elements of human resources}

The state and private employers, being competitors in the attraction of highquality labor, at the same time are a united interested party in the development of personnel potential.

This means that the education system must be the most important subject of the innovation economy in new conditions, which ensures the generation of knowledge and the formation of an innovative people who are able to use it in practice. The educational sector should provide training to industrial structures that create hightech products and services to take part in the formation of new knowledge allowing the formation of elements of human resources.

In our opinion, it is possible to classify elements of personnel potential under the content of the knowledge reflected by a person. Using this criterion, it is possible to allocate the following components of personnel potential:

- The basic potential which is formed by the knowledge creating a basis of a profession or a field of activity, production. It is part of the qualification of a certain worker and staff of the organization. The basic potential has a value for work in any workplace, for any employer, being rather stable.

- The technological potential based on technological knowledge as a form of a capital resource of production. Thus, technological 
knowledge leans on some basic level. Technological potential includes, in our opinion, methodologies and techniques of production of goods, the software, databases, organizational structure and mechanisms providing productivity of workers and functioning of the company, economic communications and interactions as a part of the production technology, distribution and exchange. Here is a set of the intellectual assets used in the course of good production, beginning from the stage of its development till the final release: scientific and technical ideas and development, general, scientific and professional knowledge, experience and qualification of all people, organizational culture of the enterprise, administrative technologies, etc.

A person is not aloof from the work, he is not only professionally qualified, but also is initiative, more independent in decision-making, is guided well in the work of his position and the enterprise in general. Thus, the worker, the employer and the educational environment get the task not only to form a necessary skill level, but also to create a system of its continuous support. In modern conditions, it has to provide performance of two functions: compensations of an insufficient practical orientation or bad education of graduates of the system of professional education, on the one hand, and ensuring adaptation of the worker at the workplace, on the other hand. Thus, it is necessary to understand that the workplace gets out the person not once in life, it can change with the development of the organization of an employer and, therefore, the requirements to qualification can change, too.

The whole system of quantitative and quality indicators, which are external and internal conditions of the environment in which processes of formation and use of personnel potential are carried out, has an impact on the formation, preservation, realization, development and, respectively, quality of personnel potential.

The quantitative indicators include gender and age structure of the personnel, qualification structure of the personnel, coefficients of the movement of the personnel, indicators of efficiency of work, efficiency of working hours, number of the personnel, qualification structure, completeness on positions, specialties, professions, etc.

Qualitative components of personnel potential also have a special value in innovative economy.

Personnel potential is not homogeneous. It is characterized by the existence of a difficult structure as people are very different on the mental, physical and psychological abilities and characteristics. Also, distinctions on the level of the education and professional preparation are important.

A set of target indicators which impact the formation of elements of personnel potential is as follows:

- physical potential - the number of workers, health, vital activity, etc.;

- intellectual potential - educational structure, innovation activity, creative activity, etc.; 
- labor potential - professional structure, business activity, etc.;

- moral potential - corporate culture, ethics, legal activity, etc.

According to this structure, personnel potential can be calculated using the formula:

$$
P P=a_{1} P_{p h}+a_{2} P_{i}+a_{3} P_{1}+a_{4} P_{m}
$$

where:

$\mathrm{P}_{\mathrm{ph}}$ - physical potential of the personnel of the company;

$\mathrm{P}_{\mathrm{i}}$ - intellectual potential of the personnel of the company;

$\mathrm{P}_{1}$ - labor potential of the personnel of the company;

$\mathrm{P}_{\mathrm{s}}$ - moral potential of the personnel;

$a_{i}-$ weight coefficients of each potential determined by an expert method.

The complex of the mentioned above indicators and some other ones can give an idea about the quantitative and qualitative status of the staff of the company and its trends for the purpose of personnel management, including planning, analysis and development of measures to improve efficiency in the use of labor resources.

At the same time, although the presence of professional competencies, knowledge and skills is required, they do not guarantee success. A decisive role is played by the orientation of a person on a permanent self-development appropriate to the dynamics of economic relations. People working in the organization, their attitude to work, skills, creativity and intellectual level will determine the success of the organization. In this regard, it is important to realize that the emphasis in personnel management only on the technical aspect of the development will not give the expected results. Ignoring social factors leads to the fact that domestic sources of growth remain unclaimed.

This shows the need to strengthen the social orientation of enterprises, unlock the potential of the individual, change the criteria for evaluating the effect of production and management activities, more active involvement of the state in regulating the processes of accumulation and management, human capital, including its professional component and health. In this case, we underline filling available jobs by skilled workers as well as the preparation of personnel reserve for projected high-tech jobs.

Thus, the primary task of the state at the present stage is to ensure the sustainable development of human resources development, taking into account the social aspects of ensuring consistency control mechanisms to the development of innovative processes in the future.

\section{Conclusions}

1. In the sectors of Kazakhstan's economy, the shortage of competence and skills continues to grow. The qualification level of workers increasingly lags behind the requirements of the labor market. At the same time, there is an effect of 
qualification loop when the lack of necessary skills by personnel leads to restraining the economic growth of the economy.

2. The registered unemployed in Kazakhstan is currently without a job for more than 12 months. At the same time, new jobs annually open, which, however, are not filled by these applicants. This indicates that the level of their skills does not meet the needs of open positions.

3. Outstripping the industrial development of Kazakhstan's economy needs in increasing the availability and quality of human resources makes the demand to the quality of education. The main focus of industrialization of the economy of Kazakhstan is aimed at intensive growth of production, namely, the growth of labor productivity. Therefore, system-wide measures to ensure human resource capacity are focused not on the number of created jobs, but the quality of the training of highly qualified, innovative and scientific personnel.

4. Formation of innovative development of the state demands the corresponding development of social relations and productive forces, in particular - human resources. The efficient economy organization determines the production of competitive products and the use of resource-saving technologies. A necessary condition for this is the high quality of the labor force, the formation of the flexible and quickly react labor market with the trends and challenges of economic development of industries and regions. However, despite the importance of all market mechanisms, the regulatory role of the state as a facilitator of economic development should be maintained and qualitatively improved.

5. Kazakhstan should actively participate in the competition for highly skilled labor force to get the possible benefits and advantages of the international division of labor. In this regard, it is necessary to create effective mechanisms for assessing the need for foreign labor from the perspectives of the development of the national economy and the labor market. Differentiated approaches to regulate short-term and long-term labor migration, including the use of various mechanisms of selection, conditions of entry, stay and implementation of employment should be the introduced.

6. It is necessary to undertake a study of factors of emigration and immigration of qualified personnel to counter the outflow of skilled labor force. A work should also be carried out to encourage migration to the permanent residence of foreign skilled professionals and their families in demand in the labor market.

7. For the development of human resources in the innovation economy, it is necessary to improve the system of training of qualified personnel. Target indicators should lie in the basis of preparation of specialists (physical, intellectual and spiritual potential of labor) affecting the formation of elements of human resources. Therefore, the trend in the modernization of education is the orientation towards consumers who prefer the flexibility of professional thinking, communication skills, ability to work in a team. Also, taking into account the specialization of regions of Kazakhstan, the development of regional innovation clusters identifies universities 
and colleges aimed at training highly qualified specialists for the priority sectors of the economy.

\section{References}

1. Address of the President of the Republic of Kazakhstan. Leader of the Nation Nursultan Nazarbayev to the people of Kazakhstan "Strategy "Kazakhstan-2050": New Political Course of the Established State" of 14 December 2012 [interactive]. <http://www. akorda.kz/ru/page/page_poslanie-prezidenta-respubliki-kazakhstan-n-nazarbaevanarodu-kazakhstana-14-dekabrya-2012-g_1357813742>.

2. Agency on Statistics of the Republic of Kazakhstan. Economic Activity of the Population of Kazakhstan. Statistical Yearbook. Astana, 2014,- p. 188.

3. Armstrong, M. Practice of Human Resource Management. Transl. from English. Ed. S.K. Mordovina. 8th ed. SPb.: Peter, 2004,- p. 832.

4. Becker, G. S. Human Capital and the Personal Distribution of Income: An Analytical Approach. NY: Columbia University Press, 1967,- p. 467.

5. Chen, C. J., and Huang, J. W. Strategic Human Resource Practices and Innovation Performance - The Mediating Role of Knowledge Management Capacity. Journal of Business Research. 2009, 62(1): 104-114.

6. Dakhli, M., and De Clercq, D. Human Capital, Social Capital, and Innovation: A MultiCountry Study. Entrepreneurship \& Regional Development. 2004, 16(2): 10-128.

7. Dyatlov, S.A. Human Capital Theory. SPb.: SPSUEF, 1996,-- p. 141.

8. Kibanov, A.Y. (ed.). Personnel Management: Textbook. 2nd ed. ext. and rev. M.: INFRA-M, 2002,- p. 638.

9. Maydyrova, A.B. Human Capital of Kazakhstan in the Information Economy. Monograph. Astana, 2004, p. 290.

10. Meldahanova, M.K. Human Capital and Sustainable Development of Kazakhstan: Theory, Priorities and Implementation Mechanism. Almaty, 2011,- p. 341.

11. Mescon, M.H., Albert, M., and Khedouri, F. Management. M.: Business, 1994,- p. 680.

12. Ministry of Labour and Social Protection. The Migration Situation in the Republic of Kazakhstan for 4 Months in 2014 [interactive]. <http://www.e-cis.info/page. php?id=24264>.

13. Mukhamedzhanova, A.G. Human Capital of Kazakhstan: The Formation, State, Use. Almaty: SIC Gylym, 2001,-- p. 376.

14. Report on Attracting Foreign Experts to the Republic of Kazakhstan. Information from the Official Site of the Ministry of Health and Social Development of the Republic of Kazakhstan [interactive]. <www.mzsr.gov.kz>.

15. Resolution of the Government of the Republic of Kazakhstan "On the Rules and Conditions for the Issuance of Permits to Foreign Workers for Employment and to Employers for Attracting Foreign Labor Force" dated January 13, 2012, No. 45 [interactive]. <http://adilet.zan.kz/rus/docs/P1200000025>.

16. Schultz, T. Investment in Human Capital. The American Economic Review. 1961, 1(2): $1-17$. 
17. The Law of the Republic of Kazakhstan "On Employment" dated January 23, 2001, No. 149-II (with amendments and additions dated 29.12.2014) [interactive]. $<$ http://online. zakon.kz/Document/?doc_id=1021547>.

18. The State Program for Development of Education of the Republic of Kazakhstan for 2011-2020. Approved by Decree of the President of the Republic of Kazakhstan dated December 7, 2010, No. 1118 [interactive]. <http://www.edu.gov.kz/ru/strategy/ gosudarstvennaya-programma-razvitiya-obrazovaniya-respubliki-kazahstan-na-20112020-gody>.

19. The State Program of Forced Industrial-Innovative Development of Kazakhstan for 2015-2019. Approved by Decree of the President of the Republic of Kazakhstan dated August 1, March 2014, No. 874 [interactive]. <http://online.zakon.kz/Document/?doc $\mathrm{id}=31588425>$.

20. ripon, A., and Blaga, P. Stimulation of the Innovative Potential in Online Life Long Training of Human Resources. Scientific Bulletin of The Petru Maior University of Targu Mures. 2011, 8(2): 262-266.

21. Vesnin, V.R. Practical Management of Personnel: A Handbook for Personnel Work. M.: Yurist, 1998.

22. Zakirova, D.I. Human Potential as a Factor of Improving the Competitiveness of the Republic of Kazakhstan. Almaty, 2012,- p. 136.

\section{Bauyrzhan S. Yessengeldin, Diana A. Sitenko, Aissulu N. Ramashova \\ Žmogiškųjų išteklių potencialo plètojimas Kazachstano inovacijų ekonomikoje}

\section{Anotacija}

Straipsnyje analizuojama dabartinè Kazachstano Respublikos darbo rinkos situacija ir pateikiama ekonomiškai aktyvių gyventojų dinamika. Identifikuojami teigiami ir neigiami veiksniai, turintys ịtakos Kazachstano ekonominių sektorių žmogiškųjų išteklių potencialui. Autoriai identifikuoja tokius žmogiškųjų išteklių potencialo struktūrinius elementus: pagrindinès kompetencijos ir technologiniai gebejjimai. Straipsnyje nustatomi pagrindiniai rodikliai, parodantys šalies žmogiškųjų išteklių formavimosi bruožus. Atsižvelgiant ị analizuotus veiksnius, pateikiamos kvalifikuoto, inovacijų ekonomikai skirto personalo dalyvavimo ir mokymo rekomendacijos.

Bauyrzhan S. Yessengeldin, Karagandos E. A. Buketovo valstybinio universiteto Ekonomikos fakulteto dekanas, profesorius, ekonomikos mokslų daktaras.

E-paštas yessen_baur@inbox.ru

Diana A. Sitenko, Karagandos E. A. Buketovo valstybinio universiteto docentè, ekonomikos mokslų daktarè.

E-paštas daesha@list.ru

Aissulu N. Ramashova, Eurazijos L. N. Gumiliovo nacionalinio universiteto doktorantė.

E-paštas rgul.ksu@mail.ru 
Bauyrzhan S. Yessengeldin, Doctor of economic sciences, Buketov Karaganda State University, Dean of economic faculty, professor

E-mail: yessen_baur@inbox.ru

Diana A. Sitenko, PhD in Economics, E.A. Buketov Karaganda State University, associate professor.

E-mail: daesha@list.ru

Aissulu N. Ramashova, $2^{\text {nd }}$-year doctoral student, L.N. Gumilyev Eurasian National University E-mail: rgul.ksu@mail.ru

Straipsnis įteiktas redakcijai 2015 m. kovo mėn.; recenzuotas; parengtas spaudai 2015 m. birželio mèn. 